\title{
PENINGKATAN PROFESIONALISME SUMBERDAYA MANUSIA MELALUI PENDIDIKAN VOKASI YANG BERBASIS KEBUTUHAN MASYARAKAT
}

\author{
Dewi Auditiya Marizka ${ }^{(1)}$ \\ ${ }^{(1)}$ Sekolah Tinggi Manajemen Industri-Departemen Perindustrian RI
}

\begin{abstract}
ABSTRAK
Kecenderungan pemenuhan kebutuhan manusia dalam hal barang dan jasa makin meningkat. Kecenderungan kebutuhan dan sekaligus tantangan ini pada akhirnya bermuara pada tuntutan terpenuhinya sumberdaya manusia (SDM) yang profesional dan produktif. Tantangan ini perlu dihadapi dengan menata dan mengatur kembali peran pendidikan vokasi di Indonesia. Pendidikan vokasi dan pendidikan umum sesungguhnya merupakan pilihan layanan yang dapat dipilih secara bebas oleh masyarakat. Pengembangan pendidikan vokasi seyogyanya dikembangkan tidak hanya melalui sekolah, namun juga melalui pendidikan vokasi yang berjenjang perguruan tinggi dan dapat dibentuk secara formal. Selain itu, pengembangan pendidikan vokasi perlu dikembangkan secara integral dengan pengembangan komunitas dan berbasis kebutuhan masyarakat/lingkungan. Kecenderungan kebutuhan dan tantangan ini pada akhirnya bermuara pada tuntutan terpenuhinya sumberdaya manusia (SDM) yang professional dan produktif. Sesungguhnya lembaga pendidikan tinggi memiliki peran besar dalam merencana dan menciptakan SDM tingkat menengah yang profesional dan produktif.
\end{abstract}

Keyword: pendidikan vokasi

\section{PENDAHULUAN}

Sesungguhnya di era global ini telah terjadi dinamika di berbagai bidang dan segmen kehidupan manusia. Perubahan kecenderungan kebutuhan manusia di satu sisi, dan tantangan untuk memenuhi kebutuhan tersebut di sisi lain. Kecenderungan akan pemenuhan kebutuhan manusia dalam hal barang dan jasa makin meningkat, baik dilihat dari sisi produsen (penghasil) mau pun konsumen (pengguna). Dapat dilihat misalnya kebutuhan akan pemilihan (1) jenis, kualitas, dan daya saing harga suatu produk, (2) teknologi yang digunakan, (3) distribusi produk: pasar, layanan, dan (4) informasi yang concurrent.

Pada tingkat pendidikan menengah sebagaimana yang dituangkan dalam KepMendiknas RI No: 053/U/2001 tentang Standar Pelayanan Minimal (SPM). Dalam Lampiran-5 keputusan ini dijelaskan bahwa tujuan penyelenggaraan pendidikan vokasi adalah untuk meningkatkan pengetahuan dan keterampilan siswa untuk menyiapkan mereka sebagai tenaga kerja tingkat menengah yang terampil, terdidik, dan profesional, serta mampu mengembangkan diri sejalan dengan perkembangan ilmu pengetahuan dan teknologi. Apakah ini berarti bahwa perubahan kecenderungan kebutuhan dan tantangan SDM yang profesional dan produktif sudah teratasi?

\section{INTI BAHASAN}

\subsection{Profesionalisme SDM}

Apa sesungguhnya profesionalisme itu? Menurut Rosenzweig (1979) bahwa pengertian profesional terkait dengan ciri-ciri sebagai berikut:

1. Profession have a systematic body of theory. Skill is achieve through a lengthy process of training.

2. The professional has authority based upon superior knowledge which is recognized by his clientele.

3. There is a broad social sanction and approval of the exercise of this authority.

4. There is a code of ethics regulating relations professional persons with clients and with colleagues.

5. There is a culture sustained by organizations. A professional is a member of many formal and informal groups. The interactions of social roles required by these groups generate a social configuration unique to the profession, a professional culture.

Ini berarti bahwa profesional tidak sekedar skill yang berbasis pengetahuan, namun juga termuat nilai (norma agama, sosial, dsb) dan sikap. Bagaimana sesungguhnya profesionalisme dibangun? Melalui 
pendidikan khusus: pendidikan profesional atau melalui pendidikan vokasi.

\subsection{Pendidikan Vokasi}

Istilah vokasi mungkin diturunkan dari bahasa Inggris, vocation, sama artinya dengan profession. Di AS, vokasi digunakan untuk menyebut pengelompokan sekolah kejuruan seperti di sini. Sistem pendidikan tinggi di Indonesia dipilah untuk akademik dan profesional atau vokasi.

Dari tingkatan S-1 sampai S-3, arahan akademik di perguruan tinggi di negeri ini lebih mapan, meluluskan jenjang sarjana, magister, dan doktor. Program pascasarjana untuk berbagai bidang ilmu telah berkembang lama. Sebaliknya untuk vokasi umumnya masih pantok sampai tingkatan D-3 dan amat jarang yang menyelenggarakan program D-4, apalagi program pascaprofesional atau pascavokasi. Padahal, untuk jenjang itu terbuka.

Ketika Prof Juwono Sudarsono menjadi Menteri Pendidikan dan Kebudayaan pernah dikeluarkan peraturan menteri atau keputusan menteri yang mengatur dua jalur dalam pendidikan tinggi, yakni jalur akademik dan profesi. Pada jalur profesi dicantumkan dalam perundang-undangan, jumlah SKS yang harus ditempuh mahasiswa untuk mencapai jenjang D-1 sampai D-4, bahkan dari D-4 untuk mencapai spesialis satu dan spesialis dua di tingkat pendidikan pasca masing-masing lulusan jenjang D-4 setingkat sarjana, sedangkan spesialis satu dan spesialis dua masing-masing setingkat magister dan doktor.

Wenrich dan Wenrich (1974: 6) menyebutkan bahwa pendidikan vokasi adalah the total process of education aimed at developing the competencies needed to function effectively in an occupation or group of occupations. Makna yang tersirat dalam definisi ini ialah:

(1) pengembangan kompetensi,

(2) kompetensi yang dibutuhkan,

(3) kompetensi yang dikembangkan dapat berfungsi efektif, dan

(4) kompetensi yang dikembangkan terkait dengan suatu pekerjaan - atau kelompok pekerjaan.

Pendidikan vokasi merupakan pendidikan yang bersifat khusus (terspesialisasi) dan meliputi semua jenis dan jenjang pekerjaan. Penafsiran yang tidak benar ialah memaknakan pendidikan vokasi sebatas pada pendidikan yang hanya concern pada manual skills. Pendidikan vokasi sesungguhnya concern dengan mental, manual skills, values, dan attitudes (Wenrich dan Wenrich, 1974: 8). Oleh karena itu, di dalam pendidikan vokasi secara implisit terkandung unsur-unsur berpikir (cognitive), berbuat (psychomotor), dan rasa (affective) dalam proporsi yang berbeda mengikuti kebutuhan kompetensi pada jenis dan jenjang pekerjaan yang terkait. Selain itu, konsep ini menunjukkan pula bahwa pendidikan vokasi terdapat pada semua jenjang pendidikan: dasar, menengah, tinggi. Hal ini dapat dipahami bahwa pekerjaan tertentu membutuhkan kualifikasi/kompetensi SDM yang berbeda. Perbedaan kualifikasi/kompetensi ini merujuk adanya jenjang dalam kompetensi.

Pendidikan vokasi merupakan salah satu bagian dari pendidikan khusus. Ilustrasi yang disampaikan oleh Wenrich dan Wenrich (1974) ialah seperti yang terlihat dalam Gambar 1 berikut.

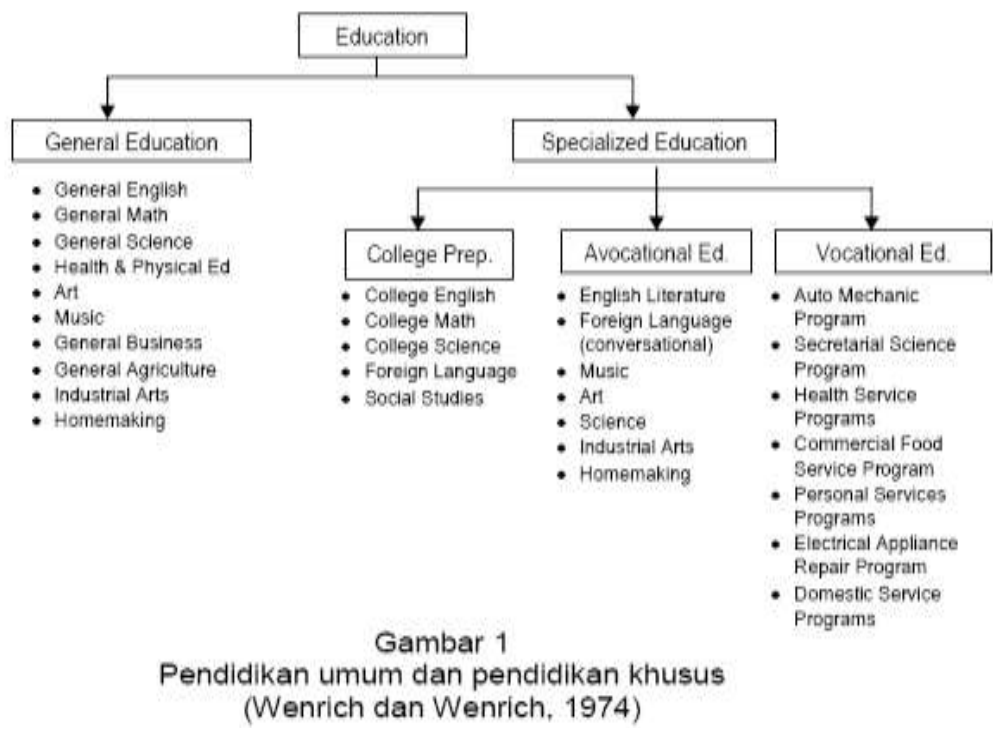

Tampak dalam Gambar 1 bahwa pendidikan khusus dilayani dengan pendidikan dalam bentuk college, avocational (minat pribadi), dan vocational (terspesialisasi). Implikasi dari pendapat ini ialah bahwa pendidikan umum dan pendidikan vokasi (istilah di Indonesia) sematamata merupakan jenis 
pilihan pendidikan yang disediakan untukdiselaraskan dengan kepentingan/kebutuhan masyarakat pengguna. Pendidikan umum berbasis pada keilmuan sedang pendidikan vokasi berbasis pada dunia kerja. Namun demikian di dalam pelaksanaannya ada perbedaan dimana sebagai pandangan umum (yang telanjur tidak benar) pelaksanaan program diploma atau katakan itu sama dengan program profesional atau program vokasi, menjadi "jalan lain" untuk memasuki jalur akademik. Dari D-3, banyak lulusan yang tidak bekerja sesuai pendidikan vokasinya, lalu berusaha pindah jalur melanjutkan sekolah untuk mendapat jenjang kesarjanaan melalui jalur akademik. Bahkan, tidak sedikit yang mengambil program studi lain, meski pindah jalur ini akan makan banyak waktu, biaya, dan energi.

Hal ini bisa dipandang amat merugikan, baik dari segi pembiayaan perguruan tinggi, pembiayaan orangtua mahasiswa, maupun dari kepentingan pengembangan profesi yang seharusnya bisa ditingkatkan dengan banyaknya lulusan program profesional perguruan tinggi dalam profesi itu. Kondisi itu lalu seperti menjadi "salah kaprah" sehingga keputusan suatu perguruan tinggi yang menutup kesempatan "pindah jalur" tiba-tiba menjadi amat mengejutkan atau mengecewakan mahasiswa. Sebab, sebelumnya tidak diprogramkan bagi pelaksanaan pelanjutan jenjang D-3 ke D-4 dalam suatu program vokasi tertentu.

Konsekuensi mendirikan program diploma bagi suatu vokasi harus terpikirkan sampai program D-4, bahkan sampai pendidikan pasca untuk mencapai jenjang spesialis satu dan spesialis dua. Kenyataan lain, adanya program ekstensi yang merupakan pelaksanaan program "pindah jalur" di suatu perguruan tinggi yang sama.

Program ini hendaknya ditinjau kembali jika pendidikan vokasi hendak dikembangkan dalam suatu perguruan tinggi. Konsekuensinya perlu dikembangkan SDM pengajarnya untuk sampai pelayanan di tingkat pasca, dengan pendidikan lanjutan, jika perlu ke luar negeri. Tidak berbeda dengan pengembangan SDM pengajar untuk jalur akademik dulu.

\subsection{Basis Kebutuhan Masyarakat}

Finlay, et.al. (1998) telah mendokumentasikan dorongan dan perubahan kebutuhan masyarakat di berbagai negara: Skotlandia, Irlandia, Taiwan, Singapura, Jerman, Finlandia, Amerika Serikat, Afrika Selatan. Dorongan dan perubahan kebutuhan masyarakat ini melahirkan pemahaman pentingnya mendorong peningkatan kesejahteraan masyarakat melalui peningkatan peran pendidikan vokasi. Namun demikian, hal ini juga tidak berarti bahwa pendidikan umum bukan merupakan hal yang penting. Ini adalah soal pilihan masyarakat berdasarkan dorongan kebutuhannya.

Di Indonesia, atau di negara mana pun, pasti masyarakatnya ingin hidup sejahtera. Di Amerika Serikat, misalnya, pemerintah mendorong produktivitas pertanian dengan melaksanakan pengolahan produksi mulai dari hulu hingga ke hilir. Oleh karena itu, kebijakan pemerintah (termasuk pendidikan) diarahkan untuk mendukung mekanisasi pertanian dari hulu hingga ke hilir. Di sini peran pendidikan vokasi dikedepankan untuk membangun SDM dalam berbagai jenis dan jenjang. Demikian pula, di Taiwan, majunya sektor informal di sana dijadikan landasan untuk mengembangkan teknologi terapan. Di sini pula peran pendidikan vokasi didorong untuk mem-back-up misi ini. Lantas bagaimana dengan Indonesia?

Tiap wilayah di Indonesia sesungguhnya memiliki berbagai karakteristik potensi, misalnya: kelautan, perikanan, pertanian, kehutanan, perdagangan, dsb. Potensi ini sebenarnya dapat menjadi basis pengembangan kesejahteraan masyarakat. Apa makna pendidikan vokasi bidang teknologi bagi masyarakat pantai? Bukankah lebih bermakna menjadi pendidikan vokasi bidang perikanan atau kelautan? Apakah berarti masyarakat di pantai tidak memerlukan pendidikan umum? Jawabnya ialah perlu. Hal ini mengingat masyarakat tentu masih ada yang ingin mengembangkan bidang ilmu tertentu. Yang menjadi persoalan utama ialah bagaimana menentukan dan mengatur implementasi pendidikan umum dan pendidikan vokasi.

\subsection{Arah Pengembangan Perguruan Tinggi}

Salah satu bentuk implementasi konsep-konsep pendidikan ialah mengatur penyelenggaraan pendidikan melalui persekolahan. Dasar pemikiran mengenai pendidikan vokasi yang telah disampaikan perlu diterapkan dalam persekolahan dengan mengikuti prinsip-prinsip tertentu. Prinsip yang perlu dikembangkan dalam mengatur persekolahan tingkat menengah di antaranya ialah:

1. Pendidikan umum dan pendidikan vokasi merupakan jenis layanan pendidikan yang dapat dipilih secara bebas oleh masyarakat.

2. Program Strata 1 (S1) merupakan salah satu jenis program pendidikan tinggi yang berkonsentrasi pada pendidikan umum

3. Program Diploma IV (DIV) merupakan salah satu jenis program pendidikan tinggi yang berkonsentrasi pada pendidikan vokasi .

4. Layanan pendidikan vokasi di Perguruan Tinggi didasarkan pada kebutuhan masyarakat pengguna. 
5. Implikasi dari prinsip-prinsip di atas setidaknya ada dua, yaitu

(1) Mengatur kembali tugas pendidikan umum dan pendidikan vokasi,

(2) Mengatur kembali bahwa implementasi pendidikan vokasi tidak hanya melalui persekolahan SMK,

(3) Mengatur proses migrasi.

Tujuan pendidikan dapat dikembangkan menurut tiga pandangan secara terpisah maupun gabungan yaitu: intellectualist, vocationalist, dan humanist (Johari, 2004). Membedakan pendidikan (persekolahan) menjadi pendidikan umum dan pendidikan vokasi sesungguhnya adalah pilihan yang diskriminatif, tetapi pada hakikatnya memang berbeda tujuan belajarnya.Untuk mengembangkan pendidikan menjadi pendidikan umum dan pendidikan vokasi dengan rincian tugas seperti uraian berikut ini.

Pendidikan umum berfokus pada pengembangan kemampuan intelektual dan memberikan sedikit porsi untuk pengembangan skill, sedangkan pendidikan vokasi berfokus pada pengembangan skill dan memberikan sedikit porsi untuk pengembangan intelektual. Skill yang dimaksud di sini ialah kemampuan atau keterampilan yang berorientasi pada job di semua bidang yang memungkinkan. Kemudian, pada kedua jenis pendidikan ini dikembangkan pula pembentukan kepribadian. Kepribadian yang dibentuk adalah kepribadian yang berorientasi harkat dan martabat manusia. Kepribadian yang berorientasi harkat dimaksudkan untuk membentuk pribadi religi, misalnya sholeh, bermoral, jujur, hemat, bersemangat, menghormati sesama. Kepribadian yang berorientasi martabat dimaksudkan untuk membentuk pribadi intelectualist (pendidikan umum) dan pribadi professionalist (pendidikan vokasi). Lalu, berdasarkan pengalamannya manusia tentu akan mengalami perubahan mind-set-nya. Dapat dilihat, misalnya, temuan Wenrich dan Wenrich (1974: 4-6). Perubahan mind-set ini tentu telah melalui proses yang panjang. Untuk itu, perlu diterapkan prinsip dual track schooling sebagai fasilitas "migrasi". Proses migrasi perlu diatur. Untuk mengatur migrasi, dapat dikembangkan Competencies and Academic Auditing.

Seseorang dapat bermigrasi dari ke Perguruan Tinggi vokasi tertentu setelah melalui competencies auditing. Demikian pula, migrasi seseorang dari Perguruan Tinggi vokasi tertentu ke Perguruan Tinggi / Universitas tertentu dapat diakui setelah melalui proses academic auditing. Persoalan pengembangan Perguruan Tinggi vokasi sangat ditentukan oleh efektivitas atau pun efisiensi program studi yang ditawarkan sebagai layanan khusus. Untuk itu, perlu adanya pemetaan program studi sehingga dapat diketahui dan dikaji mana yang efektif atau efisien dan mana yang tidak.

Salah satu indikator yang dapat digunakan untuk melihat efisiensi eksternal pendidikan vokasi ialah mengukur seberapa tingkat terserapnya llulusannya di dunia kerja yang sesuai bidangnya dan seberapa tingkat penghargaan dunia kerja terhadap kompetensi tersebut. Pemikiran ini mengarahkan pada ide bahwa pengembangan pendidikan vokasi menjadi bagian integral dari pengembangan komunitas. Dengan model ini diharapkan pendidikan vokasi merupakan bagian dari masyarakat itu sendiri. Dan oleh sebab itu, potensi lingkungan (termasuk di dalamnya komunitas manusia) akan menjadi strategis sebagai basis pengembangan program studi di Perguruan Tinggi vokasi. Prinsip yang dijadikan dasar pengembangan pendidikan vokasi ialah bahwa

(1) Pengembangan sumber belajar harus memanfaatkan sumberdaya dan potensi lingkungan,

(2) Program belajar dikembangkan berbasis lingkungan dan masyarakat.

Dengan demikian, pengembangan pendidikan vokasi harus diselaraskan dengan kebutuhan masyarakat/lingkungan, memanfaatkan sumberdaya lingkungan, memberdayakan lingkungan, serta menjaga keharmonisan hubungan dengan masyarakat/lingkungan. Selain itu, dalam implementasinya, pendidikan vokasi tidak hanya diwujudkan dalam bentuk SMK. Sebagaimana temuan dan ide disampaikan oleh Wenrich dan Wenrich (1974), maka pemerintah dapat mengoptimalkan pendidikan vokasi antara lain Diploma III dan Diploma IV. Reorientasi dilakukan untuk mengatur kembali menata agar menjadi lebih baik lagi khususnya dapat memiliki efisiensi eksternal, yaitu tingkat terserapnya tenaga kerja yang dihasilkan perguruan tinggi vokasi pada dunia kerja dan seberapa penghargaan dunia kerja terhadap kompetensi tamatan.

Selain itu, sebagaimana yang telah dilakukan oleh masyarakat, secara formal pemerintah membangun pusat-pusat pendidikan vokasi sebagai model. Dapat dilihat kembali, misalnya, sekolah maupun perguruan tinggi vokasi dibawah Kementerian Perindustrian

(STMI,APP,STTT,ATK,ATIM,SMTI,PTKI,dll).

Hadirnya pendidikan vokasi tersebut mendapat sambutan sangat masyarakat. Masyarakat industri, sekolah, perdagangan, atau pun masyarakat umum telah mempercayai kualitas tamatan yang dihasilkan oleh Pendidikan Vokasi. 


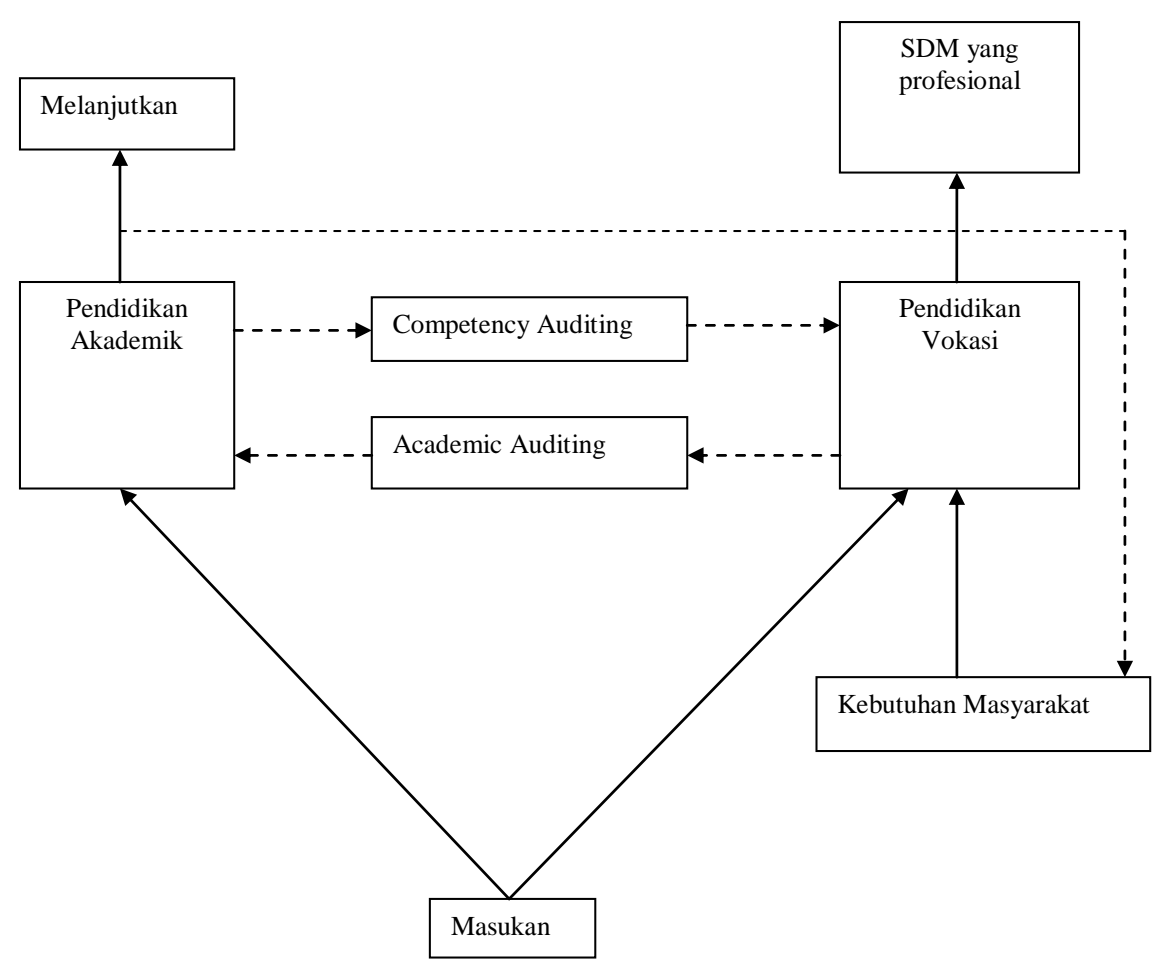

Gambar 2 Pola pengembangan SDM melalui pendidikan vokasi

Sementara itu, langkah perluasan pendidikan vokasi bukan mengarah pada upaya mengatur komposisi jumlah sekolah (SMK maupun perguruan tinggi vokasi) namun lebih ditekankan pada kompetensi pendidikan vokasi misalnya Sekolah Tinggi Teknologi Tekstil, Akademi Teknologi Kulit, dll.

\subsection{Kedudukan Dalam Jenjang Pendidikan}

Perlu ditegaskan bahwa program diploma adalah program pendidikan di tingkat pendidikan tinggi yang berorientasi kepada keperluan pembangunan, yaitu untuk menyiapkan tenaga - tenaga ahli dan terampil untuk memenuhi kebutuhan tenaga kerja bagi pembangunan. Hal ini berarti bahwa setiap lulusan dari setiap jenjang program diploma dipersiapkan untuk terjun ke masyarakat untuk bekerja. Kemungkinan untuk melanjutkan ke jenjang pendidikan yang lebih tinggi dalam jalur program non - gelar masih terbuka seperti tercantum dalam penjelasan PP Nomor 27 - tahun 1981 dan SK Menteri Nomor 0211/U/1982.

Program Diploma dapat memenuhi salah satu dari 2 pola berikut :

1. Pola pendidikan yang bulat (terminal) atau pola multiple entry - multiple output (Lihat bagan I)

2. Pola pendidikan yang berjenjang atau pola "single entry - multiple output (Lihat Bagan II)
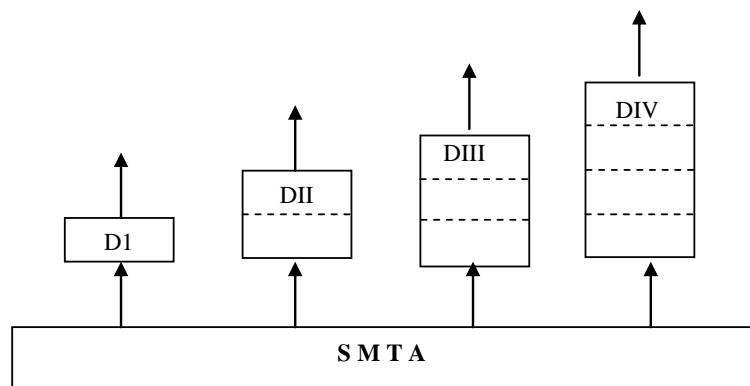

Bagan I : Pendidikan Bulat "multiple entry - multiple output" 


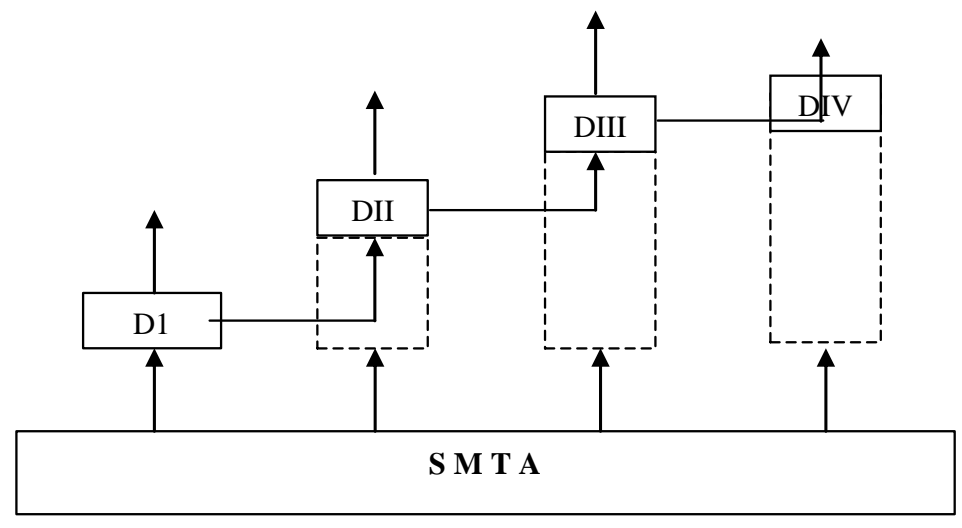

Bagan II : Pendidikan berjenjang single entry multiple output

Pola pendidikan yang bulat adalah suatu proses pendidikan yang terminal yaitu Program D1, DII, DIII dan DIV merupakan satu kesatuan (Paket) program pendidikan.

Program pendidikan yang berjenjang adalah proses pendidikan yang berkelanjutan, yaitu setiap jenjang dapat menghasilkan lulusan yang siap pakai.

Program pendidikan yang berjenjang mungkin lebih sesuai untuk keperluan pendidikan kedinasan, oleh karena tenaga - tenaga lulusan tiap jenjang langsung bisa dimanfaatkan di samping pola ini lebih memungkinkan pembinaan karir yang bertahap.

Lulusan tiap jenjang tersebut dapat melanjutkan pendidikan ke jenjang yang lebih tinggi dengan melalui persyaratan - persyaratan tertentu seperti :

a. Telah bekerja selama waktu tertentu pada bidangnya

b. Rekomendasi dari pimpinan instansi tempat bekerja

c. Syarat - syarat lain yang ditentukan oleh penyelenggara program pendidikan, misalnya : indeks prestasi yang baik, lulus ujian masuk dan sebagainya.

Meskipun pada dasarnya pada pola pendidikan yang bersifat bulat (terminal) tiap - tiap program bersifat terminal; demi perkembangan karir, hendaknya para lulusan diberi kesempatan untuk melanjutkan pendidikannya untuk mencapai jenjang pendidikan yang lebih tinggi dengan memenuhi persyaratan tertentu seperti pola pendidikan berjenjang.

\subsection{Seperti setengah hati}

Pelaksanaan program pendidikan vokasi di perguruan tinggi ini seperti "setengah hati" atau "setengah jadi". Mudah-mudahan konotasi seperti itu hanya mengada-ada. Memang perlu pemikiran lebih mendalam dengan dasar, pembangunan negeri ini memerlukan kompetensi kesarjanaan dan keprofesionalan, bahkan untuk keprofesionalan dibutuhkan lebih banyak.
Seorang sarjana di suatu ilmu harus berbeda dengan seorang profesional di bidang keilmuan itu. Kompetensi seorang sarjana farmasi tentu berbeda dengan keprofesionalan seorang apoteker. Di bidang ilmu benih, seorang sarjana ilmu benih, katakan misalnya fisiolog benih, berbeda kompetensinya dengan seorang profesional produsen atau analis benih di industri benih.

Di bidang ilmu lain tentu bisa dilahirkan kurikulum pendidikan berbeda guna melahirkan seorang sarjana dan seorang profesional. Saat ini mungkin yang umumnya dipegang sebagai perbedaan adalah rasio antara jumlah pelajaran teori dan praktiknya. Padahal, seharusnya bukan hanya sampai sedangkal itu. Harus pula didalami apa yang akan dikerjakan lulusan nanti di masyarakat. Baru disusun kurikulum yang tepat. Dengan demikian, akan lebih jelas bagaimana kompetensi seorang sarjana dan profesional dalam suatu cabang keilmuan. Akan lebih adil dan manusiawi jika keduanya bisa mencapai setinggi-tingginya martabat dalam hidupnya sesudah keluar dari pendidikan tinggi, baik sebagai sarjana maupun profesional.

\section{KESIMPULAN}

Sesungguhnya tuntutan profesionalisme di era global merupakan hal yang tidak dapat dihindarkan dari kehidupan bernegara dan bermasyarakat. Tantangan ini harus dihadapi dengan menata dan mengatur kembali peran pendidikan vokasi di Indonesia. Pengembangan pendidikan vokasi seyogyanya dikembangkan tidak hanya melalui SMK, namun juga melalui perguruan tinggi vokasi.

Pelaksanaan program pendidikan vokasi di perguruan tinggi ini seperti "setengah hati" atau "setengah jadi", sehingga perlu pemikiran lebih mendalam dengan dasar, pembangunan negeri ini memerlukan kompetensi kesarjanaan dan keprofesionalan, bahkan untuk keprofesionalan dibutuhkan lebih banyak. 
Pendidikan vokasi dan pendidikan umum sesungguhnya merupakan pilihan layanan yang dapat dipilih secara bebas oleh masyarakat, untuk itu perlu diberikan fasilitas migrasi. Selain itu, pengembangan program studi di persekolahan pendidikan vokasi perlu dikembangkan secara integral dengan pengembangan komunitas dan berbasis kebutuhan masyarakat/lingkungan.

\section{PUSTAKA}

1. Depdiknas. (2001). KepMendiknas RI No. 053/U/2001. Pedoman Penyusunan Standar Pelayanan Minimal Penyelenggaraan
Persekolahan Bidang Pendidikan Dasar dan Menengah. Jakarta: Depdiknas.

2. Finlay, Ian, dan Niven, Stuart, dan Young, Stephanie (Eds). (1998). Changing Vocational Education and Training: An International Comparative Perspective. London: Routledge.

3. Johari, Khir. 2004. My philosophy of education.

4. Wenrich, R.C., dan Wenrich, J.W. (1974). Leadership in Administration of Vocational and Technical Education. Columbus: Charles E Merrill Publishing Company, A Bell \& Howell Company. 